\title{
EFFECT OF CUTANEOUS LEISHMANIASIS ON SOME HAEMATOLOGICAL AND IMMUNOLOGICAL PARAMETERS IN PATIENTS FROM AREAS OF NORTH BAGHDAD / IRAQ
}

\author{
${ }^{*}$ AL-Hoot, A. S.," Taha, S. A. and ${ }^{* *}$ Hussein, Z. T. \\ * Professor of parasitology and protozoology, Faculty of science, Zagazig University** \\ Researcher at faculty of veterinary, Tikrit University, Iraq
}

\begin{abstract}
The current study was conducted to determine the effect of cutaneous leishmaniasis on some haematological and immunological parameters. 80 samples are examined from patients in areas of north Baghdad - Iraq. Patients are (40 males and 40 females), and 40 samples from healthy persons (20 males and 20 females) as a control group from December 2016 to August 2017. Results of the haematological parameters showed a significant increase in the number of red blood cells (RBC) of infected females compared to non-infected, while there is no significant difference between infected and non-infected males. Significant decrease in packed cell volume (PCV) is found in infected males, while there is no difference in infected females compared to non- infected. There is also significant decrease in haemoglobin $(\mathrm{Hb})$ concentration in the infected females and males compared when compare with the control group. There was a significant decrease in the white blood cell count (WBC) in infected females, while there is no difference in males. There is a significant increase in lymphocyte and monocyte in both males and females compared to control, while there is a significant increase in neutrophil for males, and there is no difference in females. The results of immunological parameters showed that there were 62 positive for IgG cases and 18 for positive IgM cases, thus indicating 62 positive cases and 18 negative anti-nucleic antibody (ANA) cases. There was no significant difference according to the different ages, for both sexes with the result obtained for ANA. Regarding interleukin (IL-10) level there is significant difference between the ages in female and males' groups, there is no significant difference between the sexes and the type of infections. There is a significant difference in concentration of interleukin depending on the duration of the infection.
\end{abstract}

Keywords: Leishmania, Chronic, Acute, Immunological parameters 


\section{Introduction}

With all the world development in technology and medicine and health care, yet, there are about 17 Neglected tropical diseases (NTD) which affect one billion people worldwide. Due to the lake of health care policy and different crises facing poor and even developed countries, such diseases were commonly diagnosed in countries suffer from Poverty, economic crisis or other reasons including war. Diseases such as schistosomiasis, trypanosomiasis and leishmaniasis, can be chronic and health threating diseases. As world environmental conditions change, tropical neglecting diseases are increased worldwide, as they infect more people in more countries, especially in tropical and subtropical countries, (WHO,2013). Diseases caused by parasites have great negative impact on human and animal health and play an important role in causing devastating burden for hundreds of millions of people all over the world in Asia, Europe, and South and North America. These diseases are of primary public health importance, especially those caused by protozoa including those caused by the order Trypanosomatida and Family of Trypanosomatidae, to which Leishmania species is belonging and the genus Plasmodium to which Plasmodium malariae is the causative agent of malaria infection. Leishmaniases, a vector- born NTD caused by Leishmania protozoa transmitted among humans by female sand-fly, Lutzomyia usually associated with bad health management, impoverished situation, which reported that Leishmanasis protozoa disease recrudescence in nearly 98 countries and affect about 12 million people, as it caused by special strain called Leishmania tropica, and other strains of Leishmania (Doroodgar et al, 2009). The increased spread of leishmaniasis in different areas and among people, means that there are more information about its epidemiology has become available nowadays, yet there is still much more to discover and understand, (Hotez and Kamath, 2009). The present study was planned to look after changes occur in blood and immunological parameters due to cutaneous Leishmaniasis (CL): Haematological parameters. Such as, (red blood corpuscle (RBC), packed cell volume (PCV\%), haemoglobin concentration (Hb), white blood cell count (WBCs), and deferential count, (lymphocyte, monocytes and neutrophils) are studied and the impact of CL on some of the immunological parameters. Such as, IgM, IgG, ANA and IL-10.

\section{Material and methods}

\section{Blood samples collection}

The blood samples are collected from 80 patients, 40 males (M) and 40 females (F), and 40 samples from healthy persons (20 M and $20 \mathrm{~F})$ as 
control group, in North of Baghdad Province-Iraq. During the period from December 2016 to August, 2017. Five ml. of venous blood are withdrawn from arm veins for each individual. Two ml. blood are placed in an anticoagulation tubes with EDTA as an anti-coagulant used for blood picture tests (RBC, PCV, Hb, WBC, and white blood cells differential count (Lymphocyte, Monocyte and Neutrophil): $3 \mathrm{ml}$. blood are placed in centrifuge tubes and allowed for complete coagulation in room temperature, then after that are centrifuged at 3000 RPM. The sera are collected and dispensed in plastic Eppendorf tubes and stored at $-20^{\circ} \mathrm{C}$ until used for immunological tests (ANA and IL-10):

1 - The blood tests (RBC, PCV, $\mathrm{Hb}$ ) are determined by the Haemoanalyser.

2- Anti-nuclear antibodies (ANA): are determined by using kit supplied from Cayman Chemical Company (U.S.A): The kit uses enzyme linked immune assay (ELIZA) based on biotin double antibody sandwich technology.

3- interleukin 10 (IL-10): is determined using kit supplied from Cayman Chemical Company (U.S.A): The kit uses enzyme - linked immune assay (ELIZA) based on biotin double antibody sandwich technology.

\section{Statistical analysis}

Statistical analysis is performed using one-way ANOVA (SAS) Values in the tables were expressed as Mean \pm S.D

\section{Results}

\section{1 :Effect of CL on some haematological parameters:}

\section{1-1: Determination of (RBC), (PCV) and (Hb)}

Table -1 . shows that there is a significant increase in the total number of red blood cells $(\mathrm{RBC})$ in infected females $(4.82 \pm 0.62)$ millions $/ \mathrm{ml}(\mathrm{M} / \mathrm{ml})$, when compared to control females which reached to $(4.11 \pm 0.39) \mathrm{M} / \mathrm{ml}$. While there is no significant difference found between the infected and healthy males $(5.0 \pm 0.34)$ and $(5.2 \pm 0.10) \mathrm{M} / \mathrm{ml}$. respectively.

PCV results show no significant difference between healthy and infected females $(38.04 \pm 0.53 \%)$, $(38.8 \pm 2.00 \%)$, respectively, While PCV in infected males decreased to $(40.8 \pm 5.4 \%)$ with control comparative males $(44.24 \pm 2.66 \%)$ :

For haemoglobin test $(\mathrm{Hb})$, the results show a significant decrease in infected females $(12.3 \pm 0.8 \mathrm{~g} / \mathrm{dl})$ when compared with healthy ones (14.1 $\pm 1.3 \mathrm{~g} / \mathrm{dl}$ ), and there is a significant decrease in infected males (14.2 \pm 1.9 $\mathrm{g} / \mathrm{dl})$ comparative with control males $(15.1 \pm 1.08 \mathrm{~g} / \mathrm{dl})$ : 
Table -1: Determination of (RBC), (PCV) and (Hb)

\begin{tabular}{||c|c|c|c|c|}
\hline \multirow{3}{*}{ Groups } & \multicolumn{2}{|c|}{ Female } & \multicolumn{2}{c|}{ Male } \\
\cline { 2 - 5 } & $\begin{array}{c}\text { Control (20) } \\
\text { average } \pm \text { SD }\end{array}$ & $\begin{array}{c}\text { Patients (40) } \\
\text { average } \pm \text { SD }\end{array}$ & $\begin{array}{c}\text { Control (20) } \\
\text { average } \pm \text { SD }\end{array}$ & $\begin{array}{c}\text { Patients (40) } \\
\text { average } \pm S D\end{array}$ \\
\hline $\mathrm{RBC}$ & $\begin{array}{c}4.11 \pm 0.39 \\
\mathrm{a} / \mathrm{ml}\end{array}$ & $\begin{array}{c}4.82 \pm 0.617 \\
\mathrm{a}\end{array}$ & $\begin{array}{c}5.2 \pm 0.10 \\
\mathrm{a}\end{array}$ & $\begin{array}{c}5.0 \pm 0.34 \\
\mathrm{~A}\end{array}$ \\
\hline \multirow{2}{*}{$\mathrm{PCV} \%$} & $\begin{array}{c}38.04 \pm 0.53 \\
\mathrm{c}\end{array}$ & $\begin{array}{c}38.8 \pm 2.00 \\
\mathrm{c}\end{array}$ & $\begin{array}{c}44.240 \pm 2.654 \\
\mathrm{a}\end{array}$ & $\begin{array}{c}40.8 \pm 5.4 \\
\mathrm{~b}\end{array}$ \\
\hline \multirow{2}{*}{$\mathrm{Hb} \mathrm{g} / \mathrm{dl}$} & $\begin{array}{c}14.1 \pm 1.3 \\
\mathrm{~b}\end{array}$ & $\begin{array}{c}12.3 \pm 0.8 \\
\mathrm{c}\end{array}$ & $\begin{array}{c}15.1 \pm 1.08 \\
\mathrm{a}\end{array}$ & $\begin{array}{c}14.2 \pm 1.9 \\
\mathrm{~b}\end{array}$ \\
\hline
\end{tabular}

*There are significant differences between different letters $(\mathrm{P} \leq 0.05)$ :

The different small letters in the table $(\mathrm{a}, \mathrm{b}, \mathrm{c}, \mathrm{d})$ refer that there are significant $(\mathrm{P} \leq 0.05)$ difference in the same level horizontally. While the large letters $(\mathrm{A}, \mathrm{B}, \mathrm{C}, \mathrm{D})$ refer that there are significant in the same column.

\section{1-2: Determination of (WBCs) and differential count for Lymphocyte,} Monocyte, and Neutrophil

Table-2. shows a significant increase in the total number of white blood cells (WBCS) in infected females $(7.83 \pm 1.04)$ when compared with control group $(6.00 \pm 0.50)$, while there was no significant difference observed between infected and control group $(7.65 \pm 1.40),(7.42 \pm 0.60)$ respectively. Lymphocytes show a significant increase in infected females (39.57 \pm $4.30 \%)$ compared to control females $(36.80 \pm 4.20 \%)$ : The results also show a significant increase in infected males $(42.90 \pm 2.70 \%)$ when compared with healthy males $(27.30 \pm 6.40 \%)$ :

The results of monocyte show a significant increase in infected females $(7.80 \pm 1.29 \%)$ when compared to control group $(6.65 \pm 0.88 \%)$ : The results also show a significant increase in infected males compared to control group $(6.68 \pm 1.03 \%)(6.07 \pm 0.54 \%)$, respectively.

The results show that neutrophil shows no significant differences in infected and control group $(4.59 \pm 0.98 \%)(4.39 \pm 0.99 \%)$ respectively, while there is a significant increase in infected males $(5.04 \pm 0.70 \%)$ compared with the control group $(3.90 \pm 0.88 \%)$ : 
Table-2.: Determination of (WBCs), (Lymphocyte), (Monocyte) and Neutrophil

\begin{tabular}{|c|c|c|c|c|}
\hline \multirow[b]{2}{*}{ Groups } & \multicolumn{2}{|c|}{ Female } & \multicolumn{2}{|c|}{ Male } \\
\hline & $\begin{array}{l}\text { Control } \\
(20) \\
\text { Average } \\
\pm \text { SD }\end{array}$ & $\begin{array}{c}\text { Patients } \\
(40) \\
\text { average } \\
\pm \text { SD }\end{array}$ & $\begin{array}{l}\text { Control } \\
(20) \\
\text { average } \\
\pm S D\end{array}$ & $\begin{array}{c}\text { Patients } \\
(40) \\
\text { average } \\
\pm \text { SD }\end{array}$ \\
\hline WBCs & $\begin{array}{c}6.00 \pm 0.50 \\
B\end{array}$ & $\begin{array}{c}7.83 \pm 1.04 \\
\mathrm{a}\end{array}$ & $\begin{array}{c}7.420 \pm 0.598 \\
\mathrm{a}\end{array}$ & $\begin{array}{c}7.65 \pm 1.40 \\
a\end{array}$ \\
\hline $\begin{array}{c}\text { Lymphocyte } \\
\%\end{array}$ & $\begin{array}{c}36.79 \pm 4.20 \\
C\end{array}$ & $\begin{array}{c}39.57 \pm 4.30 \\
b\end{array}$ & $\begin{array}{c}27.30 \pm 6.40 \\
\mathrm{~d}\end{array}$ & $\begin{array}{c}42.90 \pm 2.70 \\
a\end{array}$ \\
\hline Monocyte \% & $\begin{array}{c}6.65 \pm 0.88 \\
B\end{array}$ & $\begin{array}{c}7.80 \pm 1.29 \\
\mathrm{a}\end{array}$ & $\begin{array}{c}6.07 \pm 0.54 \\
c\end{array}$ & $\begin{array}{c}6.68 \pm 1.03 \\
b\end{array}$ \\
\hline Neutrophil \% & $\begin{array}{c}4.39 \pm 0.99 \\
B\end{array}$ & $\begin{array}{c}4.59 \pm 0.98 \\
b\end{array}$ & $\begin{array}{c}3.90 \pm 0.88 \\
\mathrm{c}\end{array}$ & $\begin{array}{c}5.04 \pm 0.70 \\
a\end{array}$ \\
\hline
\end{tabular}

*There were significant differences between different letters $(\mathrm{P} \leq 0.05)$ :

\section{2: Effect of infection on some Immune parameters}

\section{2-1: Detection of antibody IgM, IgG:}

Table- 3. shows results of the current study carried out among 40 females and 40 males infected with CL. 10 and 8 cases of IgM are positive in females and males respectively. While 30 and 32 are $\operatorname{IgG}$ positive in females and males respectively. There are no significant differences between males and females.

Table-3: Detection of antibody IgM, IgG

\begin{tabular}{|c|c|c|c|}
\hline \multirow{2}{*}{ Groups } & Patients & $\operatorname{IgM}$ & $\operatorname{IgG}$ \\
\cline { 3 - 4 } Female & 40 & + ve & + ve \\
\hline Male & 40 & 10 & 30 \\
\hline Total & 80 & 18 & 32 \\
\hline \multicolumn{3}{|c}{ Chi-Square $=0.287 ; \quad$ P-Value $=0.866$} \\
\hline
\end{tabular}

2-2-1: Detection of anti-nucleic antibody (ANA) according to the sex Table- 4. shows the results of the ANA tests, where 30 infected females are positive for ANA and 10 infected females are negative. While in males 32 are positive for ANA and 8 are negative. Statistical results showed no significant differences between males and females. 
Table (4): distribution of ANA according to the sex

\begin{tabular}{||c|c|c|c|}
\hline \multirow{2}{*}{ Groups } & Patients & \multicolumn{2}{|c|}{ ANA } \\
\cline { 3 - 4 } Females & 40 & 30 & -ve \\
\hline Males & 40 & 32 & 10 \\
\hline Total & 80 & 62 & 18 \\
\hline \multicolumn{2}{|c|}{ Chi-Square $=0.287 ; \quad$ P-Value $=\mathbf{0 . 8 6 6}$} \\
\hline
\end{tabular}

2-2-2: Result of ANA test according to the age group and sex (Table -5) show the results of ANA based on sex and age show that the highest incidence is in the age group from 7 months to 10 years, with a total of 14 cases involving 8 males and 6 females. While the lowest percentage is in the age group $40 \geq$ years; 11 cases involving (5 males and 6 females): There are no significant differences between males and females according to age groups

Table-5: ANA test according to the age group and sex

\begin{tabular}{|c|c|c|c|c|}
\hline \multirow{2}{*}{ Groups } & \multirow{2}{*}{$\begin{array}{c}\text { Patients } \\
\text { Female andMale }\end{array}$} & Female & Male & \multirow{2}{*}{ Total +ve } \\
\hline & & $+\mathrm{ve}$ & +ve & \\
\hline 7M-10Y & 16 & 6 & 8 & 14 \\
\hline 11-20Y & 16 & 6 & 6 & 12 \\
\hline 21-30Y & 16 & 5 & 7 & 12 \\
\hline $31-40 Y$ & 16 & 7 & 6 & 13 \\
\hline $40 \geq Y$ & 16 & 6 & 5 & 11 \\
\hline Total & 80 & 30 & 32 & 62 \\
\hline \multicolumn{5}{|c|}{ Chi-Square = 0.723; } \\
\hline
\end{tabular}

\section{2-3-1: Result of Interleukin IL-10 according to the age group and sex}

(Table -6) Results showed that there were a significant difference in IL-10 between the different age groups, the highest percentage in females was opserved in the age group from 7 months-10years $(97.7 \pm 3.6)$, While the lowest percentage in the age group $40 \geq(59.5 \pm 1.7)$. On the other hand, there was a significant difference in IL-10 between the different age male groups, the highest percentage was in the age group $40 \geq(87.75 \pm 1.46)$, while the lowest percentage was in the age from 31- 40years $(52.6 \pm 2.1)$, 
The present data showed also that there was a significant difference between females and males in different age groups.

Table (6): IL-10 according to the age group and sex

\begin{tabular}{|c|c|c|}
\hline${ }_{\text {Age }}^{\text {Groups }}$ & $\begin{array}{c}\text { Female } \\
\text { average } \pm \text { SD }\end{array}$ & $\begin{array}{c}\text { Male } \\
\text { average } \pm \text { SD }\end{array}$ \\
\hline 7M-10Y & $\begin{array}{c}\text { 97.7 } \pm 3.6 \\
\text { Aa }\end{array}$ & $\begin{array}{c}63.5 \pm 5.2 \\
\mathrm{Cb}\end{array}$ \\
\hline $11-20 Y$ & $\begin{array}{c}84.3 \pm 4.0 \\
\mathrm{Ba} \\
\end{array}$ & $\begin{array}{c}66.58 \pm 3.0 \\
\text { BCb }\end{array}$ \\
\hline 21-30Y & $\begin{array}{c}79.1 \pm 2.7 \\
\text { Ba }\end{array}$ & $\begin{array}{c}70.98 \pm 1.1 \\
\text { Bb }\end{array}$ \\
\hline $31-40 Y$ & $\begin{array}{c}81.7 \pm 2.3 \\
\mathrm{Ba}\end{array}$ & $\begin{array}{c}52.6 \pm 2.1 \\
\mathrm{Db}\end{array}$ \\
\hline $40 \geq Y$ & $\begin{array}{c}59.5 \pm 1.7 \\
\mathrm{Cb}\end{array}$ & $\begin{array}{c}87.75 \pm 1.46 \\
\mathrm{Aa}\end{array}$ \\
\hline
\end{tabular}

*There are significant differences between different letters $(\mathrm{P} \leq 0.05)$ :

\section{2-3-2: Result of IL-10 according to the sex and type of infection}

Table-7 shows that there significant differences in the IL10 percentage of dry and wet between males and female.

Table (7): IL-10 percentage in both infected males and females.

\begin{tabular}{|r|c|c||}
\hline & $\begin{array}{c}\text { Female } \\
\text { average } \pm \text { SD }\end{array}$ & $\begin{array}{c}\text { Male } \\
\text { average } \pm \text { SD }\end{array}$ \\
\hline Dry & $101.9 \pm 26.9$ & $66.1 \pm 39.7$ \\
\hline Wet & $114.5 \pm 26.6$ & $87.82 \pm 9.5$ \\
\hline \multicolumn{2}{|r|}{ T-Value $=-1.19 \quad$ P-Value $=\mathbf{0 . 3 0 0}$} & ns \\
\hline
\end{tabular}

\section{2-3-3: IL-10 and duration (Months) of Infection}

Table- 8 shows IL10 percentage during the course of infection. The higher percentage $(106.77 \pm 21.46)$ is found in less than one month old infected patients and decreased with course of the infection. The lowest percentage of IL10 (64.28 \pm 3.30$)$ is found in patients after 3-4 months after infection. 
Table (18): IL-10percentage and duration (Months) of Infection course

\begin{tabular}{|c|c|c|c|c|}
\hline $\begin{array}{c}M \leq 1 \\
\text { average } \pm \text { SD }\end{array}$ & $\begin{array}{c}1-2 M \\
\text { average } \pm \text { SD }\end{array}$ & $\begin{array}{c}2-3 M \\
\text { average } \pm \text { SD }\end{array}$ & $\begin{array}{c}3-4 M \\
\text { average } \pm \text { SD }\end{array}$ & $\begin{array}{c}M \geq 4 \\
\text { average } \pm \text { SD }\end{array}$ \\
\hline $\begin{array}{c}106.8 \pm 21.5 \\
\text { a }\end{array}$ & $\begin{array}{c}92.3 \pm 26.8 \\
\text { b }\end{array}$ & $\begin{array}{c}63.3 \pm 3.8 \\
\text { c }\end{array}$ & $\begin{array}{c}64.28 \pm 3.3 \\
\text { c }\end{array}$ & $\begin{array}{c}69.492 \pm 0.73 \\
\text { c }\end{array}$ \\
\hline
\end{tabular}

* There were significant differences between different letters $(\mathrm{P} \leq 0.05)$ :

\section{Discussion}

\section{Haematological parameters}

Leishmaniasis as a vector born disease affected different ages in different environmental condition causes different kinds of lesions and cellular manifestation in the skin and other organs including blood picture. In the present study results indicated an increase in RBCs in the infected peoples compared to non- infected peoples, these results were in agreement with (Chakrabarti et al, 2013). which attributed to different type of secondary anemia including numbers of red blood corpuscles, changes in the morphology of RBCs and haemoglobin content of the corpuscles (hypochromic) and may be due to nutritional deficiencies in folaet, vitamin B12 and Iron, (Varma and Naseem,2010). These results were also accompanied with decrease in PCV percentage and hemoglobin content, (Pearson et al, 2000). was found same results concerning erythrocyte count, hematocrit hemoglobin concentration, and increased in monocytes. In the present work, white blood cells were increased in CL patients including monocytes, due to the infection and allergic reaction (Grech $\boldsymbol{e t}$ al ,2000). controversial results were reported (Carneiro et al, 2012). as there were decrease in WBC in patients with leishmaniasis but this decrease was within normal value of WBC. This controversial finding may be due to duration of the infection and on the numbers of parasites ingested by monocytes and sampling time (Pass well et al, 2005).

\section{5-3: Immunological parameters}

Results obtained from the present work indicate that the mean value of antibodies (IgG and $\operatorname{IgM}$ ) were raised in the sera of patients with Leishmania. This elevation may be due to polyclonal activation of B - cells by Leishmania antigens that induces proliferation and differentiation of $\mathrm{B}-$ cells into plasma cells that secreted antibodies. Also, cytokine produced by $\mathrm{T}$ - helper cells had been implicated in the regulation of isotope switching 
of activated B - cells. Interferon- $\gamma$, preferentially secreted by Th1 subset, had been shown to stimulate the production of complement fixing $\mathrm{IgG}_{2}$ and $\mathrm{IgG}_{3}$ antibodies (Snapper and Paul ,1987), Whereas cytokine of Th2 cells IL - 10 are recognized as helpers for B-cells lymphocyte and stimulate the production of high levels of $\operatorname{IgE}$ and $\operatorname{IgM}$ and non complement - fixing $\mathrm{IgG}_{4}$ in humans (Abbas et $\boldsymbol{a l}$,1996).

Treatment resulted in reduction of the mean value of $\operatorname{IgM}$ and $\operatorname{IgG}$, whereas their value were remained higher than control. This result agrees with (Anwar, 2014). who reported that the increase levels of antileishmanial antibodies may be present for long time after treatment.

In the present study found that, the $\operatorname{IgG}$ and $\operatorname{IgM}$ in both gender which agreed with (Hailu ,1990). they revealed that Leishmania donovani a nonspecific as well as a specific antibody production, much of which is probably due to the parasite-released substances, which act as B cell mitogns. As a consequence of The B cell hyperactivity, leishmania donovani may cause hypergamma globulinaemia and it is common in all patients with Kala-azar due to the large production of IgG, IgM antibodies, after polyclonal activation of B lymphocytes, generating specific and nonspecific antibodies, besides the production of autoantibodies such as ANA and others. On the other hand, the prolonged saturation of the reticuloendothelial system infected by parasites contributes to organomegaly and mainly to splenomegaly, causing cytopenias. The study conclude that: all patients with positive ANA do not have SLE, splenomegaly is not a common sign in patients with SLE and the VL may present with cytopenias and the production of autoantibodies mimicking SLE .The most accepted hypothesis is the presence of hypergamma globulinemia, seen in almost all patients with leishmaniasis, secondary to the increased production of $\operatorname{IgG}$ and $\operatorname{IgM}$ antibodies, is due to the polyclonal activation of $\mathrm{B}$ lymphocytes leading to the production of specific antibodies and autoantibodies that, under normal conditions, are expressed in low titers (Cruellas,2013) Regarding the increase in the level of (ANA) we found in present study that the leishmaniasis cause increase in the level of it in both male and female and this result agreed with (Ozlem,2012), that explained his results due to Autoimmune phenomena are common in Leishmania infections. This might be due to a release of high amounts of self- antigens as a result of tissue destruction caused by the parasite. Release of tissue antigens may stimulate the autorea ctivity and autoantibody production. In the present study there was an increase in the level of (ANA): In the present study the IL-10 was increased in the patients groups and agreed with (Eliane, 2001) suggesting that high IL-10 production might have some predictive value for poor responsiveness to 
treatment. However, if IL-10 expression previously has been described to be significantly higher in the more slowly healing lesions on patients with LCL caused by $L$. major and to be a promoter of persistent disease in patients infected with $L$. mexicana, it is the first time that high local IL-10 expression has been associated with a poor response to treatment. Molecular mechanisms of the role of IL-10 in poor responsiveness to treatment is not yet understood (Murray,2000) the results of IL -10 confirmed the results showed patients have increased expression of IL -10 mRNA as important strategy for down - regulating $\mathrm{T}$ - cell response, the infection induce endogouns secretion of IL -10 as a mechanism of parasitism because IL- 10 seems to be responsible for inhibition synthesis of IFN $-\gamma$ the main macrophage - stimulating cytokine involved in the defense against Leishmania which facilitated the intracellular survival of parasite by down - regulating the oxidative and inflammatory response (Bhattachary et al ,2001). In fact in human severity of Leishmania has been closely associated with increased levels of IL-10 and the use of antiIL-10 antibody to block the IL-10 activity or IL-10 receptor blockade can be effective approach for the treatment of leishmaniasis (Murray et al , 2002) IL-10 has paradoxical effects on Th cell development depending on the nature of the cells (dendritic cells or primed T cells) targeted for IL-10 signaling. In the initial period of dendritic cells (DCs) activation by Leishmania preceding T cell priming, IL-10 directs DCs to produce IL-12 and promotes Th-1 cell maturation and resistance to Leishmania parasites but later, during the period of $\mathrm{T}$ cell priming, IL-10 induces Th-2 differentiation and progressive leishmaniasis (Biedermann et al, 2001; Louis et al, 2003).

In this context, we can postulate that IL-10 might regulate the response to chemotherapy for LCL by inhibiting Th1 cytokine production (IL-12 or IFN-g), by deactivation of the macrophage or by affecting the antigenpresenting cell functions, such as the expression of costimulators or major histocompatibility complex class II molecules. Furthermore, IL-10 can inhibit the maturation of dendritic cells, which are involved in the initiation of the immune response (Banchereau and Rybak,1994). The function of IL-10 as a suppressive or deactivating cytokine is well described, it has been shown to inhibit antigen presentation, antigen-specific $\mathrm{T}$ cell proliferation and type 1 cytokine production and to render macrophages refractory to activation by IFN for intracellular killing. The sterile immunity achieved in the IL-10 and IL-10/4 might be explained, at least in part, by the fact that they developed a more potent TH1 response during the acute stage, consistent with prior observations regarding IL-10 (Belkaid $\boldsymbol{e t}$ al, 2001). 


\section{References}

Abbas, A. K.; Murphy, K. M. and Sher, A. (1996): Functional diversity of helper T - lymphocytes. Nature; 383: 787 - 793.

Anwar, I. (2014): Autoantibodies status of leishmanial patients in Iraq. Advances in Life Science and Technology. 26(7):19-27.

Banchereau, J. and Rybak, M. E. (1994): In The Cytokine Hand book, $2^{\text {nd }}$ Ed.,A. Thomson ed., Academic Press, New York, 99.

Belkaid, Y., Hoffmann, K. F., Mendez, S., Kamhawi, S., Udey, M. C., Wynn, T. A., \& Sacks, D. L. (2001). The role of interleukin (IL)-10 in the persistence of Leishmania major in the skin after healing and the therapeutic potential of anti-IL-10 receptor antibody for sterile cure. Journal of Experimental Medicine, 194(10), 1497-1506.

Bhattachary, S.; Ghosh, S. and Majumdar, S. (2001): Immunodulatory role of interleukin - 10 in visceral leishmaniasis: defective activation of protein kinase $\mathrm{C}$ - mediated signal transduction events. Infection and immunity; 69: 1499 - 1507.

Biedermann,T. ; Zimmermann, S. and Himmelrich, H. (2001): IL-4 instructs TH1 responses and resistance to Leishmania major in susceptible BALB/c mice. Nat. Immunol. 2:1054-1060.

Carneiro de Freitas, J. C.; Nunes-pinheiro,D. S. ;Neto, B. E. L. (2012): Clinical and laboratory alterations in dogs naturally infected by Leishmania chagasi. Rev. Soc. Bras. Med. Trop., 45(1): diol. 00378682.

Chakrabarti, S.; Sarkar, S.; Goswami, B.K. (2013): Clinico-haematological Profile of visceral leishmaniasis in immunocompetent patients. Southeast Asian J Trop Med Public Health. 44: 143- 149.

Cruellas, M. (2013): Myositis-specific and myositis-associated patients with polymyositis and dermatomyositis. Clin. Sao. Paulo., 68(7): 909914.

Doroodgar, A. M.; Asmar, M.R.; and Razavi, M. (2009): Identifying the type of cutaneous leishmaniasis in patients, reservoirs and vectors by RAPD-PCR in Aran and Bidgol district of Esfahan Province during 2006-7. Feyz J. Kashan Univ. Med. Sci., 13: 141-146.

Eliane, B. (2001): High intralesional Interleukin-10 Messenger RNA expression in Localized Cutaneous Leishmaniasis Is associated with unresponsiveness to treatment. JID,184 (15):1627-1631.

Grech, V.; Mizzi, J.; Mangoin, M. and Vella, C. (2000): Visceral leishmaniasis in Malta an 18 year pediatric, population based study. Aroh.Dis.child. 82:381-385 
Hailu, A. (1990): Pre and Post - treatment antibody levels in visceral leishmaniasis. Trans. R. Soc. Trop. Med. Hyg.; 84: 673 - 675.

Hotez, P. J. and A. Kamath, (2009): Neglected tropical diseases in subSaharan Africa: review of their prevalence, distribution, and disease burden. PLoS Neglected Tropical Diseases, 3: e412:1-10

Louis, J.A.; Gumy, A. and Voigt, H. (2003): The use of the murine model of infection with Leishmania major to reveal the antagonistic effects that IL-4 can exert on T helper cell development and demonstrate that these opposite effects depend upon the nature of the cells targeted for IL-4 signaling.Pathol Biol (Paris) .51:71-73. Murray, H. (2000): Interleukin-12 regulates the response to chemotherapy in experimental visceral leishmaniasis.J Infect Dis;182:1497-1502.

Murray, H. (2000): Interleukin-12 regulates the response to chemotherapy in experimental visceral leishmaniasis.J. Infect. Dis; 182:1497-502.

Murray, H. W.; Lu, C. M.; Freemans and Coffman, R. L. (2002): Interleukin - 10 in experimental visceral leishmaniasis and interleukin - 10 receptors blockade as immunotherapy. Infect. Immun.; 70: 6284 6293.

Ozlem, G. (2012): Visceral leishmaniasis mimicking autoimmune hepatitis, primary biliary cirrhosis, and systemic lupus erythematosus overlap. Korean J Parasitol. 50(2): 133-136.

Passwell, J.; Shor, R.; Keren, G. and Elon, J. (2005): Human monocytes infected with Leishmaniaamastigotes enhance lymphocyte proliferation. Clin. Exp. Immunol., 60(3):565-571.

Pearson, R.D.; Sousa, A.Q. and Jeronimo, S.M.B., (2000): Leishmania species:visceral (kala-azar), cutaneous leishmaniasis in: principles and practice of infectious diseases .By: Mmandell, G.1.5th edition. ChurchillLivingstone, Philadelphia, p: 2831-2834.

SAS, Institute (2001): User's Guide, Satistic Version, SAS Institute Inc., Cary, NC., USA.

Snapper, C.M. and Paul, W.E. (1987): Interferon gamma and B - cells stimulatory factor - 1 reciprocally regulate Ig. Isotype production, Science; 236: 944 - 947.

Varma, N.and Naseem, S. (2010): Haematologic changes in visceral leishmanisis/ Kala Azar. Indian J Haematol Blood Transfus. 26: 7882.

World Health Organization (WHO) (2013): Technical Report Series on the control of the Leishmaniasis, TRS No. 949, 2010/1. 


\title{
تأثثر الاصابة بداء اللشمانيا الجلدي على بعض المعايير الدموية و المناعية

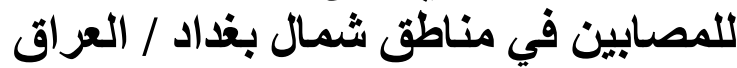

\author{
*عبد الله السيد الحوت *سمير عبدالله طه **زياد طه حسين \\ *أستاذ علم الاوليات و الطفيليات ـ قسم علم الحيوان ـ كلية العلوم - جامعة الزقازيق

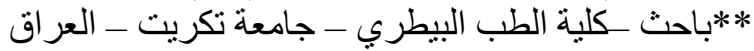

الخلاصة

أجريت الدراسة الحالية لمعرفة تأثير الاصابة باللثمانيا الجلدية على بعض المعايير الدموية

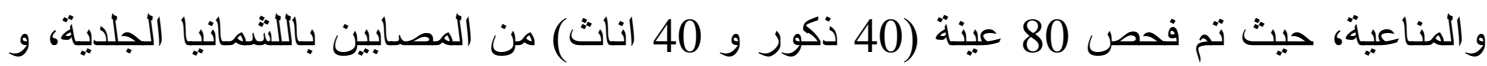
فحص 40 عينة من الاشخاص الغيرمصابين كعينات ضابطة (20 ذكور و 20 اناث) في الفترة من (ديسمبر ) 2016 إلى. اغسطس 2017 في مناطق شمال بغداد. أظهرت نتائج تحليل الدم : حدوث ارتفاع معنوي في عدد كريات الدم الحمر اء للإناث المصابات مقارنة مع غير المصابات ،بينما لم يحصل اختلاف معنوي بين الذكور الدصابين و غير المصابين. لوحظ كذلك انخفاض معنوي في حجم كريات الدم المضغوطة في الذكور المصابين، بينما لم يحصل اختلاف في الاناث المصابات مقارنة مع غير المصابات. في حين حصل انخفاض معنوي في الذكور و الاناث المصابين مقارنة بالهمو عة الضابطة. كما لوحظ حدوث انخفاض معنوي في عدد كريات الدم البيض في الاناث المصابات، بينما لم يحدث اختلاف في الذكور وارتفاع معنوي في الخلايا اللمفية والخلايا الوحيدة في كل من الذكور والاناث المصابين مقارنة بالمجموعة الانا الضابطة.

أوضحت النتائج أيضا حدوث ارتفاع معنوي في عدد الخلايا العدلة بالنسبة للاكور، ولم يحصل

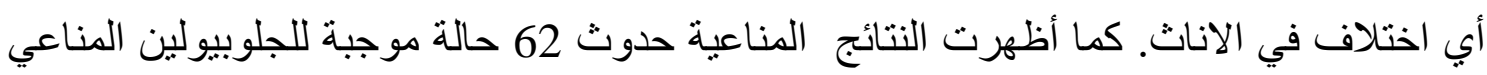

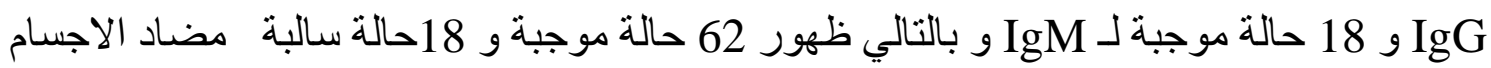
المضادة للنو اة ANA، و لم يحدث اختلاف معنوي باختلاف الفئات العمرية بالنسبة لكلا الجنسين فيما يخص نتائج فحوصات ANA، وبالنسبة لنتيجة الانترلوكين IL-10 حدث اختلاف معنوي باختلاف الفئات العمرية للإناث، و الذكور، وقد لوحظ تسجيل اختلاف معنوي بين نوع الاصابة و اختلاف الجنس، بينما حدث اختلاف معنوي في تركيز الانترلوكين اعتمادا على مدة الاصابة. 